\title{
Research on Trust Model in Online Information of Smart Government
}

\author{
Massila Kamalrudin, Hamdan Hasan Mohammad Thaiban, Safiah Sidek, Halimaton Hakimi
}

\begin{abstract}
Online data has acquired significant management importance and has a high value-creating potential for public services. A important problem here is how public entities can adapt their traditional structures and processes to the creative field of internet data to create government trust. On top of that, trust has become the main concern as it involves in creating public trust by using online information in smart government. This study aims to determine the factor of trust in using online information and the related work on trust model in online information. To do this, we have conducted systematic literature review to identify the factors that influence trust in using online information in smart governments and to compare the existing trust models in online information.
\end{abstract}

Keywords--- Trust Model, Online Information, Smart Government.

\section{INTRODUCTION}

The use of online information has brought innovation and potential to create value in the cities that are represented by the interconnected citizens, businesses, different modes of transport, communication networks, services and utilities. Also, the online information has continuously disrupted the administrative landscape of public departments around the world . Organizations and public departments have leveraged on new technologies, such as Internet of Things and cloud computing to build a connected and sustainable service delivery, high quality information, efficiency transactions, better decision making and global competitiveness ; ; ; ; The role of internet data as a source of development and innovation for the development and creation of effective and efficient public tasks and values should be explored by government services. government authorities. AlAwadi and Scholl (2013) proposed that internet government data is designed to improve efficiency in the utilization of public assets and improving public services effectiveness . To date, many works have been done to overcome the challenge faced in smart government to ensure the efficiency of usage that includes legislation and standard data policy ; ; , security protocols , interoperability ; , robust technology infrastructure ; and open data.

However, there has been limited number of works that systematically study to create the public trust on online information. Gaining public trust becomes one of the most urgent issues to cultivate the acceptance of public with government through online information to provide better services and to gain a good understanding of their communities . In order to effectively implement and offer public trust internet data on the smart government, multiple aspects, in specific the development of the new company and organizational model, as well as the development of information infrastructure and decision support systems must also be taken into consideration.

This document consists of four primary parts. The second chapter provides the review methodology following the introduction. In the third chapter you will find and discuss the results. Finally, in the fourth chapter, the conclusion

\section{METHODOLOGY}

We constructed a review protocol to search for the relevant studies based on Kitchenham systematic review approach. The basic phases of are divided by three phases which are planning, conducting and reporting. In the planning phase, we designed research questions as in Table 1. These research questions are designed to address the organization issues as aforementioned.

Table 1: Research questions and research objectives

\begin{tabular}{|l|l|}
\hline RQ1 & $\begin{array}{l}\text { What are the factors that influence trust in using the online } \\
\text { information in a smart govemment? }\end{array}$ \\
\hline RQ2 & What are the related model of trust in online information? \\
\hline
\end{tabular}

The activities of the review protocol are shown in Figure 1. The aim is to ensure that all appropriate studies are obtained for analysis. The review protocol is adopted. ScienceDirect, Springer, Scopus, IEEE Xplore and ACM Digital Library are all the main sources of the empirical research. The research is carried out using search engines. The keywords were used to make sure all appropriate papers are included in the search. (Trust OR Trust Model) AND (Dimension OR Factors OR Element) AND (Online Information OR Public Organization) AND (Approach OR Method OR Framework OR Model) AND (Smart Government) to collect all the relevant papers.

Revised Version Manuscript Received on September 16, 2019.

Massila Kamalrudin, Faculty of Information and Communication technology, Universiti Teknikal Malaysia Melaka, Melaka, Malaysia.

Hamdan Hasan Mohammad Thaiban, Abu Dhabi Police Department, Abu Dhabi, United Arab Emirates

Safiah Sidek, Institute Technology Management and Entrepreneurship, Universiti Teknikal Malaysia Melaka, Melaka, Malaysia

Halimaton Hakimi, Faculty of Information and Communication technology, Universiti Teknikal Malaysia Melaka, Melaka, Malaysia. 
Research on Trust Model in Online Information of Smart Government

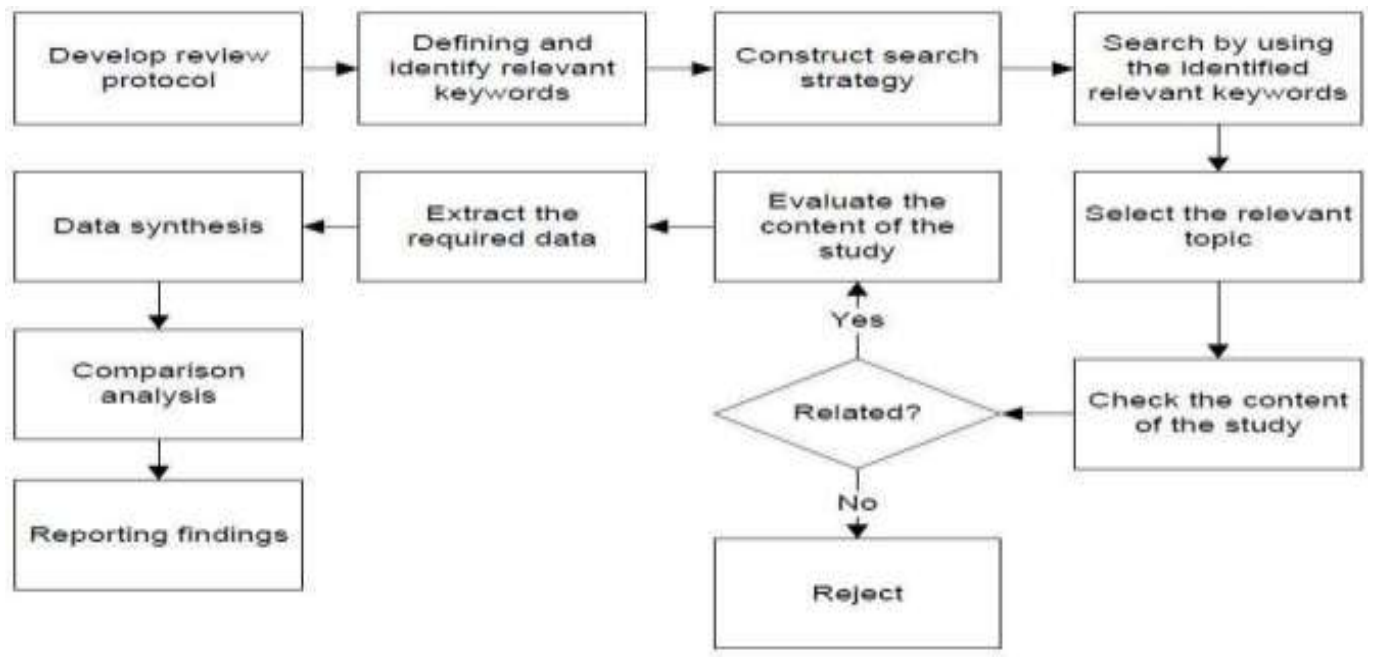

Figure 1: Review protocol process

We applied inclusion and exclusion criteria as outlined in Table 2 to collect relevant studies. By analyzing the title, abstract, and conclusion of the primary identified studies, we eliminated any unrelated studies. After applying these steps, 51 studies were retained. Furthermore, we accessed and evaluated the articles by checking the content of the articles. Irrelevant studies were rejected at this stage and the relevant studies will be analyzed. Out of 51 articles, there are only 31 articles were considered for further review. The next phase was conducting the comparison analysis and reporting the analysis of the related works.

Table 2: Inclusion and Exclusion Criteria

\section{RESULTS \& DISCUSSIONS}

We found 31 papers published between 2010 and 2017 that discussed on the topic of trust model in online information to enhance the user acceptance. For each of the papers, we identified the factor of trust followed by the type of contribution, and the domain of application of their approach. The results are presented in Table 3 and Table 4.

\begin{tabular}{|c|c|}
\hline indation Crieria & Extinies Crituris \\
\hline 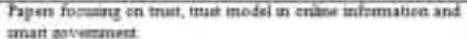 & \\
\hline 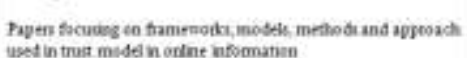 & Gtuaben undeat \\
\hline
\end{tabular}

Table 3: Trust Factor Metrics

\begin{tabular}{|c|c|c|c|c|c|c|c|c|c|c|c|c|c|c|c|c|c|c|c|c|c|c|c|c|c|}
\hline & Reference & $\underline{m}$ & 団 & $\cong$ & 9 & 目 & $\approx$ & 을 & వ & 궈 & 이 & 8 & 团 & 氞 & 8 & 気 & 8 & 8 & $\overline{8}$ & ल & 웡 & ल् & 幾 & ๙ & \\
\hline \multirow{17}{*}{ 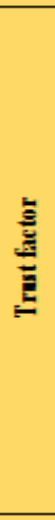 } & Supporting system & $\mathrm{x}$ & $\mathrm{x}$ & & & & & & & & $\mathrm{x}$ & $\bar{x}$ & & & & & & $\mathrm{x}$ & & & & & & $\mathrm{x}$ & 6 \\
\hline & Participation & & & & & & & & & & & & & & & & & & $\mathrm{x}$ & & & & & & $\mathbf{l}$ \\
\hline & Individual motivational & & & & & & & & $\mathrm{x}$ & & & & & & & & & & & & & & & & 1 \\
\hline & Knowledge \& experience & & $\mathrm{x}$ & & $\bar{x}$ & & $\bar{x}$ & $\mathrm{x}$ & & & & $\bar{x}$ & $\bar{x}$ & & & & & & & & & & & & 6 \\
\hline & Word of mouth & $\mathrm{x}$ & $\mathrm{x}$ & $\mathrm{x}$ & & & & & & & & & $\mathrm{x}$ & $\mathrm{x}$ & & $\mathrm{x}$ & $\mathrm{x}$ & $\mathrm{x}$ & & & & $\mathrm{x}$ & & & 9 \\
\hline & Reputation & $\mathrm{x}$ & $\mathbf{x}$ & $\mathrm{x}$ & & & $\mathrm{x}$ & & & $\mathbf{x}$ & & $\mathbf{x}$ & & & $\mathbf{x}$ & $\mathrm{x}$ & $\mathbf{x}$ & & & $\mathbf{x}$ & & & & $\mathrm{x}$ & $\begin{array}{l}1 \\
1\end{array}$ \\
\hline & Ease of use & & & $\bar{x}$ & & & & & & & $\mathrm{x}$ & $\mathrm{x}$ & & $\bar{x}$ & & & & & & & & & & $\mathrm{x}$ & 5 \\
\hline & Usefulness & & & & & & & & & & $\mathrm{x}$ & & & $\mathrm{x}$ & & & & & & & & & & & 2 \\
\hline & Website design & & & & & & & & & & & & & $x$ & & & & $\mathrm{x}$ & & & & & $\mathrm{x}$ & & 3 \\
\hline & Reliability & & & & & & & & & & & & & & & $\mathrm{x}$ & & & & & $\mathrm{x}$ & & 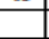 & & 2 \\
\hline & IT Quality & $\bar{x}$ & $\mathrm{x}$ & $\bar{x}$ & $\bar{x}$ & & & & $\bar{x}$ & & $\bar{x}$ & & & & & & & & & $\bar{x}$ & & & & & 7 \\
\hline & Technology & & & $\mathrm{x}$ & $\mathrm{x}$ & & & & & $\mathrm{x}$ & & & & & & & & & & & & & & & 3 \\
\hline & Risk & & & & & & $\mathbf{x}$ & & & & & & & & & & & & & & & & & & $\mathbf{l}$ \\
\hline & Culture & & & & & $\mathrm{x}$ & & & & & & & & & & & & & & & & & & & 1 \\
\hline & Brand & & & & & & & & & & & & & & & & $\mathrm{X}$ & & & 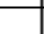 & & & . & $\mathrm{x}$ & 2 \\
\hline & Privacy & $\mathrm{x}$ & & $\bar{x}$ & $\bar{x}$ & & & & & & & & & $\mathrm{x}$ & & & & & & $\bar{x}$ & & & $\bar{x}$ & & 6 \\
\hline & Security & $\mathrm{x}$ & & $\mathrm{x}$ & $\mathrm{x}$ & & & & & & & & & & & $\mathrm{x}$ & & $\mathrm{x}$ & & $\mathrm{x}$ & & & $\mathrm{x}$ & & 7 \\
\hline & 氙 & & & & 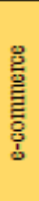 & & & & & 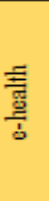 & & & & & 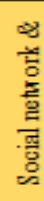 & 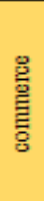 & & & & & 䇺 & & 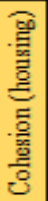 & 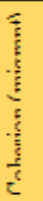 & 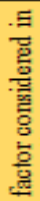 \\
\hline
\end{tabular}


Based on Table 3, "Reputation" is the most considered influencing factor of trust towards online information, which accounts for 11 studies. This is followed by "Word of mouth" in nine studies and "Security" and "IT Quality" in seven studies. This analysis also identified the factors addressed by more than 5 studies (frequency of factors) in the literature.
These are : reputation, word of mouth, security, IT quality, supporting system, knowledge \& experience, privacy and ease of use. However, it is interesting to note that there are two factors that have minimum frequency, for example risk and culture. This indicates that the factor is still underexplored in the literature.

Table 4: Related Works in Trust Model

\begin{tabular}{|c|c|c|c|c|c|c|}
\hline No & Model & Domain & $\begin{array}{c}\text { Method and } \\
\text { data (empirical) }\end{array}$ & Purpose & Findings & Source \\
\hline 1 & $\begin{array}{l}\text { Consists of internal and } \\
\text { external factors affecting } \\
\text { user trust beliefs formation }\end{array}$ & $\begin{array}{l}\text { Online } \\
\text { shopping }\end{array}$ & Conceptual & $\begin{array}{l}\text { Intention to } \\
\text { visit website }\end{array}$ & $\begin{array}{l}\text { Developing long-lasting trustful } \\
\text { relationship with users is crucial. }\end{array}$ & [36] \\
\hline 2 & $\begin{array}{l}\text { Trust as mediating variable } \\
\text { and has relation with } \\
\text { navigation functionality, } \\
\text { perceived security and } \\
\text { transaction cost. }\end{array}$ & $\begin{array}{l}\text { Commerce } \\
\text { and } \\
\text { Tourism }\end{array}$ & Survey $(n=340)$ & $\begin{array}{l}\text { Customer } \\
\text { loyalty }\end{array}$ & $\begin{array}{l}\text { Customer satisfaction influence trust } \\
\text { and has significantly effect on loyalty. }\end{array}$ & [37] \\
\hline 3 & $\begin{array}{l}\text { Integration of perceived of } \\
\text { risk to TAM model. Trust } \\
\text { as independent variable. }\end{array}$ & Banking & Survey & $\begin{array}{l}\text { Behavioural } \\
\text { Intention to } \\
\text { use }\end{array}$ & $\begin{array}{l}\text { A well-designed web will be } \\
\text { minimizing the perceived risk }\end{array}$ & [38] \\
\hline 4 & $\begin{array}{l}\text { Trust as independent } \\
\text { variable and has direct } \\
\text { relation with public } \\
\text { activities. }\end{array}$ & $\begin{array}{l}\text { Social } \\
\text { media }\end{array}$ & $\begin{array}{l}\text { Survey } \\
(\mathrm{n}=502)\end{array}$ & $\begin{array}{l}\text { Public } \\
\text { engagement }\end{array}$ & $\begin{array}{l}\text { online civic engagement is required to } \\
\text { enhance the trust among public }\end{array}$ & [39] \\
\hline 5 & $\begin{array}{l}\text { TAM model and trust and } \\
\text { flow is classified as } \\
\text { mediating variables. }\end{array}$ & $\begin{array}{l}\text { Mobile } \\
\text { banking }\end{array}$ & $\begin{array}{l}\text { Survey } \\
(\mathrm{n}=200)\end{array}$ & $\begin{array}{l}\text { Behavioural } \\
\text { Intention to } \\
\text { use }\end{array}$ & $\begin{array}{l}\text { Both trust and flow experience should } \\
\text { be taken into mobile service providers } \\
\text { consideration in order to facilitate user } \\
\text { adoption and usage of mobile banking } \\
\text { service }\end{array}$ & [40] \\
\hline 6 & $\begin{array}{l}\text { Trust (mediating variables) } \\
\text { classified as trust in } \\
\text { members and trust in } \\
\text { website. }\end{array}$ & $\begin{array}{l}\text { Social } \\
\text { media }\end{array}$ & $\begin{array}{l}\text { Survey } \\
(n=360)\end{array}$ & $\begin{array}{l}\text { Customers } \\
\text { purchase } \\
\text { intention }\end{array}$ & $\begin{array}{l}\text { Trust in other members influence } \\
\text { members ' purchase behaviour. }\end{array}$ & {$[41] ;[42]$} \\
\hline 7 & $\begin{array}{l}\text { Trust can be mediating and } \\
\text { moderating variable of } \\
\text { privacy concerns. }\end{array}$ & $\begin{array}{l}\text { Social } \\
\text { media }\end{array}$ & $\begin{array}{l}\text { Survey } \\
(\mathrm{n}=718)\end{array}$ & $\begin{array}{l}\text { Online self- } \\
\text { disclosure } \\
\text { behaviours }\end{array}$ & $\begin{array}{l}\text { Trust plays central role in online } \\
\text { disclosure of social network. }\end{array}$ & [43] \\
\hline 8 & $\begin{array}{l}\text { Trust as mediating } \\
\text { variables. }\end{array}$ & e-Banking & $\begin{array}{l}\text { Survey } \\
(n=202)\end{array}$ & $\begin{array}{l}\text { Willingness to } \\
\text { adopt e- } \\
\text { banking }\end{array}$ & $\begin{array}{l}\text { Traditional service quality at the bank } \\
\text { still required in promoting the e- } \\
\text { banking. }\end{array}$ & [44] \\
\hline 9 & $\begin{array}{l}\text { Perceived of } \\
\text { communication } \\
\text { (Gratification theory) }\end{array}$ & Health & $\begin{array}{l}\text { Survey } \\
(\mathrm{n}=4551)\end{array}$ & Internet usage & $\begin{array}{l}\text { Trust in online health information was } \\
\text { also found to be a significant predictor } \\
\text { of online health activities. }\end{array}$ & [45] \\
\hline 10 & $\begin{array}{l}\text { Trust as independent } \\
\text { variables and it is classified } \\
\text { as trust in the website, the } \\
\text { vendor, the auction initiator } \\
\text { and group members. }\end{array}$ & $\begin{array}{l}\text { Online } \\
\text { shopping }\end{array}$ & $\begin{array}{l}\text { Survey } \\
(\mathrm{n}=454)\end{array}$ & $\begin{array}{l}\text { Purchase } \\
\text { intention }\end{array}$ & $\begin{array}{l}\text { A safe, user-friendly shopping } \\
\text { environment and satisfaction can } \\
\text { enhance the decision making process in } \\
\text { online shopping. }\end{array}$ & [46] \\
\hline 11 & $\begin{array}{l}\text { Model of trust for } \\
\text { expanding the banking } \\
\text { service in a developing } \\
\text { country. }\end{array}$ & $\begin{array}{l}\text { Mobile } \\
\text { banking }\end{array}$ & $\begin{array}{l}\text { Survey } \\
(\mathrm{n}=1077)\end{array}$ & $\begin{array}{l}\text { Adoption and } \\
\text { usage }\end{array}$ & $\begin{array}{l}\text { The adequate use and construction of } \\
\text { arguments disclosed by banks about } \\
\text { how secure MB can be is also a factor } \\
\text { that banks need to observe. }\end{array}$ & [47] \\
\hline 12 & $\begin{array}{l}\text { Model of trust for cultural } \\
\text { exchange }\end{array}$ & Tourism & $\begin{array}{l}\text { Survey } \\
(n=1094)\end{array}$ & $\begin{array}{l}\text { Engagement } \\
\text { activities }\end{array}$ & $\begin{array}{l}\text { Networking technology and } \\
\text { community involvement are used to } \\
\text { generate trust in geographically } \\
\text { dispersed communities. }\end{array}$ & [48] \\
\hline 13 & $\begin{array}{l}\text { Model of trust for health } \\
\text { resource among older adults }\end{array}$ & Health & $\begin{array}{l}\text { Survey } \\
(n=1450)\end{array}$ & $\begin{array}{l}\text { Internet } \\
\text { usage, } \\
\text { usefulness, } \\
\text { and wust in } \\
\text { the internet }\end{array}$ & $\begin{array}{l}\text { Website design features has influence } \\
\text { on trust among older adults. }\end{array}$ & [49] \\
\hline 14 & Personalized service offers & $\begin{array}{l}\text { Social } \\
\text { media }\end{array}$ & $\begin{array}{l}\text { Survey } \\
(\mathrm{n}=137)\end{array}$ & $\begin{array}{l}\text { Click through } \\
\text { rate }\end{array}$ & $\begin{array}{l}\text { Trust-building marketing strategies } \\
\text { that transfer trust from another website } \\
\text { or signal trust with in formational cues } \\
\text { can of fset this negative effect }\end{array}$ & [50] \\
\hline 15 & $\begin{array}{l}\text { Use the theory of reasoned } \\
\text { action (TRA) }\end{array}$ & Health & $\begin{array}{l}\text { Survey } \\
(n=264)\end{array}$ & $\begin{array}{l}\text { Actual } \\
\text { behaviour }\end{array}$ & $\begin{array}{l}\text { Trust in website had a similar affect on } \\
\text { risk and attitude. }\end{array}$ & [51] \\
\hline 16 & $\begin{array}{l}\text { Elaboration likelihood } \\
\text { model }\end{array}$ & $\begin{array}{l}\text { Mobile } \\
\text { banking }\end{array}$ & $\begin{array}{l}\text { Survey } \\
(\mathrm{n}=240)\end{array}$ & $\begin{array}{l}\text { Adoption and } \\
\text { usage }\end{array}$ & $\begin{array}{l}\text { service providers need to employ } \\
\text { differentiated strategies to build users. } \\
\text { initial trust }\end{array}$ & [40] \\
\hline 17 & $\begin{array}{l}\text { Meta analysis on trust } \\
\text { relationship with e-vendor } \\
\text { website }\end{array}$ & e-commerce & Review & $\begin{array}{l}\text { Purchase } \\
\text { intention }\end{array}$ & $\begin{array}{l}\text { The trust is important determinant for } \\
\text { repeating purchase }\end{array}$ & [52] \\
\hline 18 & $\begin{array}{l}\text { Based on Theory of } \\
\text { Planned Behavior (TPB), } \\
\text { Theory of easoned Action } \\
\text { (TRA) and Theory } \\
\text { Acceptance Model (TAM) }\end{array}$ & e-commerce & Conceptual & $\begin{array}{l}\text { Purchase } \\
\text { intention }\end{array}$ & "t & [18] \\
\hline 19 & $\begin{array}{l}\text { Based on Theory } \\
\text { Aceptance Model (TAM) }\end{array}$ & $\begin{array}{l}\text { Mobile } \\
\text { shopping }\end{array}$ & $\begin{array}{l}\text { Survey } \\
(n=600)\end{array}$ & $\begin{array}{l}\text { Behavioural } \\
\text { intention to } \\
\text { ues }\end{array}$ & $\begin{array}{l}\text { application of mobile content and } \\
\text { service will become one niches for } \\
\text { mobile commerce }\end{array}$ & [53] \\
\hline
\end{tabular}


The studies are summarized in Table 4. The Technology Acceptance Model (TAM) has proven to be a reliable model that explains technology system acceptance. Also, it is found that trust is an important determinant whether the users decide to use online services and/or to adopt the online services. In recent years, there have been a lot of research concerning online service i.e. commerce, banking, tourism, and health. However, smart government is the next level of government in which variety of applications of newly rising technology and innovating activities. In this respect, research for understanding the trust factors and intention to use online information is still very limited.

\section{RELATED MODEL OF TRUST IN ONLINE INFORMATION}

Many work was carried out to develop the internet data trust model. For instance, a work examined factors that influence the build-up of end-user confidence in on-line shopping settings. They classified the elements according to inner and external variables which impact on the development of the end user trust. The external factors mean variables indirectly linked to the online service, while the inner elements only include those linked to a specific online service.

Next,[ 37] examined factors that affect trust and the relationship between trust and the customer loyalty of tourism products and services to shopping online. They have used a structural equation modeling to assess the navigational function, the safety and transaction cost viewed (as exogenous factors), trust and satisfaction (as mediating factors), and allegiance as a dependent variable. Their findings demonstrate that the price of the transaction is positive, but does not have a important influence on trust. Trust and satisfaction are connected with customer loyalty.

Another study of online information in online shopping domain was conducted by . They focused on building trust in virtual communities. The degree on how communities trust online shopping websites is examined by assessing the communities' intentions to get online information and purchasing information from these websites. In their study, trust of a website refers to trust towards information provided by vendors. The relationships between trust dimensions and trust in members were identified. Results show that in building trust in virtual communities, trust in members plays a more important role in fostering trust in the vendor that further affects communities' intention to get information form the virtual communities. It suggested that online forum would help the virtual communities, in which member provides topic- or interest-oriented information in its online community. In relation with trust on online information provided by vendor and members, proposed conceptual model that the behaviors of member have significant effect in purchasing intention on online shopping.

In the domain of online banking or e-commerce, the extended TAM model was shown by. The online information provided in the bank website is the key determinant of trust of e-commerce. Zhou[ 40] has examined the impact on mobile banking users ' usage behavior. 55] suggested in a consumer assessment the trustworthness of e-banking and subsequent implementation conduct a model that recognized the connection between e-banking website's digital attribute and structural certainty (the size and reputation and quality of traditional services at the industry).

\section{CONCLUSION}

An analysis of methods and model of trust model has been conducted. A list of existing works related to trust model has been presented in Table 4. Based on the analysis of existing works, work that analyzes trust factor and attention to use online information in smart governments is yet to be conducted. Moreover, most of the works in trust model focus on the industry services. There are model and method involved in various domains, which are commerce, banking, tourism, and health. The finding indicates that there is no outstanding work of trust model of online information in smart governments. For future work, we plan to develop a new trust model to enhance user acceptance using online information in smart government.

\section{ACKNOWLEDGEMENT}

The authors would like to thank the Universiti Teknikal Malaysia Melaka and Abu Dhabi Police for their support throughout this research.

\section{REFERENCES}

1. J. R. Gil-Garcia, N. Helbig and A. Ojo, "Being smart: Emerging technologies and innovation in the public sector," Government Information Quarterly, vol. 31, no. 1, pp. 11-18, 2014.

2. F. Mohammed, A. Idries, N. Mohamed, J. Al-Jaroodi and I. Jawhar, "UAVs for Smart Cities: Opportunities and Challenges," in International Conference on Unmanned Aircraft Systems (ICUAS), Orlando, FL, USA, 2014.

3. O. M. Awoleye, B. Ojuloge and M. O. Ilori, "Web application vulnerability assessment and policy direction towards a secure smart government," Government Information Quarterly, vol. 31, no. 1, pp. S118-S125, 2014.

4. N. S. Almuqarab, "Smart Government Services Adoption In The Uae: A Conceptual Model," in Proceedings of Researchfora International Conference, $\mathrm{Abu}$ Dhabi, UAE, 2017.

5. H. Alenezi and S. K. Sharma, "Development of quantitative model to investigate the strategic relationship between information quality and e-government benefits," Transforming Government: People, Process and Policy, pp. Vol. 9 Issue: 3, pp.324-351, 2015.

6. M. Romanelli, "Rethinking Public Organizations as Knowledge-Oriented and Technology-Driven Organizations," Management Dynamics in the Knowledge Economy, vol. 5, no. 1, pp. 559-576, 2017.

7. S. AlAwadhi and H. J. Scholl, "Aspirations and Realizations: The Smart City of Seattle," in 46th Hawaii International Conference on System Sciences, Hawaii, US, 2013.

8. J. C. Bertot, U. Gorham, P. T. Jaeger, L. C. Sarin and H. Choi, "Big data, open government and e-government: Issues, policies and recommendations," Information Polity, vol. 19, no. 1, pp. 5-16, 2014.

9. K. d. S. Brito and V. C. Garcia, "Brazilian Government Open Data: Implementation, Challenges, and Potential Opportunities," in ACM, 11-16, Aguascalientes, Mexico, 2014. 
10. A. Bari, J. Jiang, W. Saad and A. Jaekel, "Challenges in the Smart Grid Applications: An Overview," International Journal of Distributed Sensor Networks , pp. 1-11, 2014.

11. A. Mondorf and M. A. Wimmer, "Requirements for an Architecture Framework for Pan-European E-Government Services," in 15th IFIP WG 8.5 International Conference, EGOV 2016, 136-150, Guimarães, Portugal, 2016.

12. J. Jin, J. Gubbi, S. Marusic and M. Palaniswami, "An Information Framework An Information Framework of An Information Framework of An Information Framework of Creating a Smart City through Internet of Things," pp. 1-10, 2016.

13. M.-H. Hsu, L.-W. Chuang and S. Hsu Cheng, Understanding online shopping intention: the roles of four types of trust and their antecedents, Internet Research, pp. Vol. 24 Issue 3, pp.332-352, 2014.

14. S. Wang and X. wang, "Factors Impacting Chinese Consumers' Macro-Level Trust on B2C E-Ecommerce: An Empirical Study," in International Conference on Information Management, Innovation Management and Industrial Engineering, Taipei, Taiwan, 2008.

15. D. Nishioka, Y. Saito and Y. Murayama, "The influence of knowledge level in information security onto the factors of Anshin for online shopping users," in 47th Hawaii International Conference on System Science, Hawaii, 2014.

16. H. Jafarpour and A. Andalib, "A New Method for Determination of Effective Criteria to Evaluate Electronic Trust (E-Trust) of Online Customers," in Second International Conference on Web Research (ICWR), 2016.

17. H. Hallikainen and T. Laukkanen, "National culture and consumer trust in e-commerce," International Journal of Information Management, vol. 38, no. 1, pp. 97-106, 2018.

18. F. Meskaran, Z. Ismail and B. Shanmugam, "Online Purchase Intention: Effects of Trust and Security Perception," Australian Journal of Basic and Applied Sciences, vol. 7, no. 6, pp. 307-315, 2013.

19. H.-H. Cheng and T.-J. Fu, "The Determinants of Online Shopping Behavior," in 2018 International Conference on Intelligent Autonomous Systems, Singapore, 2018.

20. P. Kostagiolas, N. Korfiatis, P. Kourouthanasis and G. Alexias, "Work-related factors influencing doctors search behaviors and trusttoward medical information resources," International Journal of Information Management, pp. 34, pp.80-88, 2014.

21. H.-J. Paek and T. Hove, "Determinants of Vertical and Horizontal Online Health Information Behavior," in 47th Hawaii International Conference on System Science, Hawaii , 2014.

22. Y. Li, X. Wang, X. Lin and M. Hajli, "Seeking and sharing health information on social media: A net valence model and cross-cultural comparison," Technological Forecasting \& Social Change, vol. 126, no. 1, pp. 24-40, 2018.

23. C. C. Kiliroor and C. Valliyammai, "Trust Analysis on Social Networks for Identifying Authenticated Users," in 2016 IEEE Eighth International Conference on Advanced Computing (ICoAC), 2016.

24. F. Alam and A. Paul, "A Computational model for Trust and Reputation relationship in Social Network," in FIFTH INTERNATIONAL CONFERENCE ON RECENT TRENDS IN INFORMATION TECHNOLOGY, 2016.

25. A. D. Noor, R. Sulaiman and A. Abu Bakar, "A Review of Factors that Influenced Online Trust in Social Commerce," in 2014 International Conference on Information Technology and Multimedia (ICIMU), Putrajaya, Malaysia, 2014

26. S. Fong, Y. Zhuang, M. Yu and I. Ma, "Quantitative
Analysis of Trust Factors on Social Network using Data Mining Approach," in IEEE International Conference on Future Generation Commnication Technology (FGCT 2012), London, 2012.

27. S. Kim and H. Park, "Effects of various characteristics of social commerce (s-commerce) on consumers' trust and trust performance," International Journal of Information Management, vol. 33, pp. 318-332, 2013.

28. M. R. Habibi, M. Laroche and M.-O. Richard, "The roles of brand community and community engagement in building brand trust on social media," Computers in Human Behavior, vol. 37, no. 1, pp. 152-161, 2014.

29. N. Hajli, "Ethical Environment in the Online Communities by Information Ethical Environment in the Online Communities by Information," J Bus Ethics, vol. 149, no. 1, pp. 799-810, 2018.

30. A. Kavanaugh, S. D. Sheetz, H. Skandrani, J. C. Tedesco, Y. Sun and E. A. Fox, "The Use and Impact of Social Media during the 2011 Tunisian Revolution," in 2016 ACM, Shaghai, China, 2016.

31. E. Ponte, E. Carvajal-Trujillo and T. Escobar-Rodríguez, "Influence of trust and perceived value on the intention to purchase travel online: Integrating the effects of assurance on trust antecedents," Tourism Management, pp. 47, pp. 286-302, 2015

32. B. Sparks, H. Perkins and R. Buckley, "Online travel reviews as persuasive communication: The effects of content type, source, and certification logos on consumer behavior," Tourism Management, pp. 39, pp. 1-9, 2013.

33. C. Bartle, E. Avineri and K. Chatterjee, "Online information-sharing: A qualitative analysis of community, trust and social influence amongst commuter cyclists in the UK," Transportation Research Part F, pp. 16, pp. 6072, 2013.

34. D. Pal, S. Funilkul, N. Charoenkitkarn and P. Khantamanin, "Internet-of-Things and Smart Homes for Elderly Healthcare: An End User Perspective," SPECIAL SECTION ON HUMAN-CENTERED SMART SYSTEMS AND TECHNOLOGIES, IEEE Translations, vol. 6, pp. 10483-10496, 2018.

35. C. Hoffmann, C. Lutz and M. Meckel, "The Impact of User Characteristics on Online Trust," Journal of Management Information Systems, vol. 31, no. 3, pp. 138-171, 2014

36. J. Salo and H. Karjaluoto, "A conceptual model of trust in online environment," Online Information Review, pp. Vol. 31 No. 5, 604-621, 2007.

37. M.-J. Kim, N. Chung and C.-K. Lee, "The effect of perceived trust on electronic commerce: Shopping online for tourism," Tourism Management 32, pp. 256-265, 2011.

38. A. Kesharwani and S. S. Bisht, "The impact of trust and perceived risk on internet banking adoption in India: An extension of technology acceptance model," International Journal of Bank Marketing, pp. Vol. 30 Iss: 4, pp. 303-322, 2012.

39. A. M. Warren, A. Sulaiman and N. I. Jaafar, "Social media effects on fostering online civic engagement and building," Government Information Quarterly, vol. 31, pp. 291-301, 2014.

40. T. Zhou, "Examining mobile banking user adoption from the perspectives of trust and flow experience," Inf Technol Manag, pp. 13, 27-37, 2012. 
41. Y. Lu, L. Zhao and B. Wang, "From virtual community members to $\mathrm{C} 2 \mathrm{C}$ e-commerce buyers: Trust in virtual communities and its effect on consumers' purchase intention," Electronic Commerce Research and Applications, pp. 9, 346-360, 2010.

42. S. Fu, Q. Yan and G. C. Feng, "Who will attract you? Similarity effect among users on online purchase intention of movie tickets in the social shopping context," International Journal of Information Management, vol. 40, no. 1, pp. 88-102, 2018.

43. S. Taddei and B. Conten, "Privacy, trust and control: Which relationships with online self-disclosure?," Computers in Human Behavior, vol. 29, pp. 821-826, 2013

44. D. H. Wong, C. Loh, R. Bak and B. Yap K., "Offline and online banking - where to draw the line when building trust in e-banking?," International Journal of Bank Marketing, vol. 28, no. 1, pp. 27-46, 2010.

45. J. Hou and J. Shim, "The Role of Provider-Patient Communication and Trust in Online Sources in Internet Use for Health-Related Activities," Journal of Health Communication: International Perspectives, vol. 15, no. 3 , pp. 186-199, 2010.

46. C.-M. Chiu, M.-H. Hsu, H.-C. Lai and C.-M. Chang, "Re-examining the influence of trust on online repeat purchase intention: The moderating role of habit and its antecedents," Decision Support Systems, pp. 53, pp. 835845, 2012.

47. F. Rodrigo and Y. Hwang, "An empirical study on trust in mobile banking: A developing country perspective," Computers in Human Behavior, vol. 54, pp. 453-461, 2016.

48. D. Rosen, P. R. Lafontaine and B. Hendrickson, "CouchSurfing: Belonging and trust in a globally cooperative online social network," New Media \& Society, vol. 13, no. 6, pp. 981-998, 2011.

49. D. M. Zulman, M. Kirch, K. Zheng and C. A. Lawrence, "Trust in the Internet as a Health Resource Among Older Adults: Analysis of Data from a Nationally Representative Survey," J Med Internet Res, vol. 13, no. 1, pp. 1-14, 2011.

50. E. Aguirrea, D. Mahr, D. Grewal, K. d. Ruyter and M. Wetzels, "Unraveling the Personalization Paradox: The Effect of InformationCollection and Trust-Building Strategies on Online AdvertisementEffectiveness," Journal of Retailing, vol. 91, no. 1, pp. 34-39, 2015.

51. J. C. Zimmer, R. E. Arsal, M. Al-MArzouq and V. Grover, "Investigating online information disclosure: Effects of information relevance, trust and risk," Information \& Management, vol. 47, no. 1, pp. 115-123, 2010.

52. Y. Kim and R. A. Peterson, "A Meta-analysis of Online Trust Relationships in E-commerce," Journal of Interactive Marketing, vol. 38, no. 1, pp. 44-54, 2017.

53. Y.-F. Chen and Y.-C. Lan, "An Empirical Study of the Factors Affecting Mobile Shopping in Taiwan," International Journal of Technology and Human Interaction, vol. 10, no. 1, pp. 19-30, 2014.

54. M.-H. Hsu, L.-W. Chuang and C.-S. Hsu, "Understanding online shopping intention: the roles of four types of trust and their antecedents," Internet Research, pp. Vol. 24 No. 3, pp. 332-352, 2014.

55. K. B. Yap, D. H. Wong, L. Loh and R. Bak, "Offline and online banking - where to draw the line when building trust in e-banking?," International Journal of Bank Marketing, pp. Vol. 28 No. 1, pp. 27-46, 2010. 